\title{
TOLERANSI ANTAR AGAMA DAN ANTAR ETNIS DI DESA MAMAHAK TEBOQ, KALIMANTAN TIMUR
}

\author{
Yuangga Kurnia Y \\ Universitas Darussalam Gontor Ponorogo \\ E-mail: yuangga4@gmail.com
}

\begin{abstract}
This paper will research about tolerance inter-religious and inter-ethnics people in Mamahak Teboq Village, East Kalimantan. The choosing of this village based on one of representative districts in Indonesia with a majority of Protestant believers in the most moslem population country in the world. Many kinds of accusation's intolerance in Indonesia and unfriendly relations between majorityminority became a basic reason of this research. This research used three dimensions of conflict theory (personal/symbolic, relational and structural) as a theoretical framework. This research finds that the majority of non-moslem in Mamahak Teboq can tolerate every kind of Islamic faiths dan Islamic religious worship from moslem whom are minority and strangers. That case answered an accusation which said that another religious people (in this context is Christians) cannot show any tolerance in majority position.
\end{abstract}

Keywords: Majority, Tolerance, Mamahak Teboq.

\begin{abstract}
Abstrak
Tulisan ini akan meneliti tentang toleransi antar umat beragama dan antar etnis di Desa Mamahak Teboq, Kalimantan Timur. Pemilihan desa ini berdasarkan salah satu kabupaten perwakilan di Indonesia dengan mayoritas penganut Protestan di negara berpenduduk Muslim terbanyak di dunia. Banyak jenis intoleransi terhadap tuduhan di Indonesia dan hubungan yang tidak bersahabat antara mayoritas minoritas menjadi alasan dasar penelitian ini. Penelitian ini menggunakan tiga dimensi teori konflik (personal/simbolik, relasional dan struktural) sebagai kerangka teoritis. Penelitian ini menemukan bahwa mayoritas non-muslim di Mamahak Teboq dapat mentolerir setiap jenis agama Islam dan ibadah agama Islam dari muslim yang merupakan minoritas dan orang asing. Kasus itu menjawab tuduhan yang mengatakan bahwa orang beragama lain (dalam konteks ini adalah orang Kristen) tidak dapat menunjukkan toleransi dalam posisi mayoritas.
\end{abstract}

\section{PENDAHULUAN}

Keutuhan Negara Kesatuan Republik Indonesia (NKRI) kembali diuji di usianya yang menginjak 72 tahun. Usia yang cukup matang untuk menjadi suatu bangsa yang sudah stabil dan memiliki pilar-pilar penopang yang kokoh. Gelaran pemilihan presiden pada tahun 2014 lalu mulai menyulut isu-isu sektarian, etnis dan agama yang dihembuskan lewat black campaign dan hoax-hoax di dunia maya. Tidak berhenti di sana, pemilihan kepala daerah Daerah Khusus Ibukota (DKI) Jakarta pada 2017 juga meneruskan bibit perpecahan yang telah ditabur pada gelaran pilpres tersebut. Terlebih dengan tersebarnya berbagai video dan berita-berita miring dari gubernur pertahana DKI Jakarta yang sarat dengan isu sektarian dan intoleransi. Slogan "Bhinneka Tunggal Ika" terancam hanya sebatas 
tulisan yang tertulis di atas pita yang dicengkeram oleh Garuda Pancasila. Ruang gerak gubernur yang beragama dan beretnis minoritas pada akhirnya harus mengakui dominasi dan keunggulan pihak mayoritas, terlepas adanya tuduhan radikalisme ataupun terorisme yang dilancarkan pihak-pihak tertentu.

NKRI dihuni lebih dari 300 kelompok etnik/suku bangsa atau tepatnya 1.340 suku bangsa berdasarkan data Badan Pencatatan Sipil tahun 2010, yang berbicara dengan menggunakan sedikitnya 748 bahasa dan menganut satu dari 6 agama resmi negara. Seluruhnya menyebar dengan proporsi beragam mulai dari Sabang hingga Merauke. Urusan kependudukan, ekonomi, pendidikan, politik dan sosial melatarbelakangi penyebaran ini. Penyebaran ini mau tidak mau akan melahirkan komunitas antar etnis, antar bahasa ibu, antar agama dan antar budaya. Hal demikian juga melahirkan apa yang disebut kelompok mayoritasminoritas dan penduduk asli-pendatang. Suatu hal yang lazim terjadi di wilayah NKRI, mengingat jamaknya suku dan agama yang ada akan adanya interaksi antar manusia dengan mereka yang berbeda etnis dan keyakinan. Namun belakangan, sejak merebaknya isu intoleransi di Jakarta dan sekitarnya, hubungan yang sehat antara mayoritas-minoritas berpotensi terancam dan terkoyak. Konflik di Ambon, Sampit, Poso dan wilayah lainnya yang menyebarkan ketakutan dan menghilangkan banyak nyawa selalu menjadi momok akan kemungkinan terburuk dari suasana negeri yang makin memanas ini.

Artikel ini akan membahas tentang toleransi yang terbangun di sebuah desa di pedalaman Kalimantan Timur. Wilayah ini menarik untuk diteliti mengingat hubungan agama Islam yang menjadi mayoritas dan non-muslim yang menjadi minoritas dalam hal kuantitas di Indonesia sudah jamak ditemukan. Dengan jumlah 87,18\% dari 237.641.326 jiwa penduduk Indonesia, tidak sulit untuk menemukan pemeluk Islam di berbagai wilayah di Indonesia. Jumlah tersebut juga meniscayakan dominasi jumlah mereka di banyak tempat di Indonesia. Adapun desa ini berpenduduk mayoritas Dayak dan beragama Kristen Protestan dengan muslim menjadi minoritasnya. Banyak statement miring yang menggambarkan bahwa etnis tertentu dan agama tertentu di Indonesia bertoleransi dengan Islam karena mereka di posisi minoritas, bila mereka menjadi mayoritas, niscaya etnis lain dan agama lain (khususnya Islam) akan mengalami banyak intoleransi. Tulisan ini ingin menjawab tuduhan statement tersebut dengan mengangkat fenomena toleransi desa yang berpenduduk mayoritas Kristen kepada kaum muslim minoritas, semata-mata untuk menghilangkan berbagai tuduhan dan kecurigaan (suspicion) antar etnis dan antar umat beragama di Indonesia. 
Sebelum masuk ke pembahasan tentang Desa Mamahak Teboq, terlebih dahulu akan dijelaskan pengertian toleransi dan intoleransi dalam tulisan ini dan landasan teoritik yang digunakan untuk menjelaskan mengapa suatu wilayah dapat dikatakan toleran atau intoleran. Menurut id.Wikipedia.org, toleransi adalah suatu sikap saling menghormati dan menghargai antarkelompok atau antarindividu dalam masyarakat atau dalam lingkup lainnya. Sikap toleransi menghindarkan terjadinya diskriminasi sekalipun banyak terdapat kelompok atau golongan yang berbeda dalam suatu kelompok masyarakat. Istilah toleransi tidak hanya mencakup bidang keagamaan, namun mencakup berbagai bidang dan dimensi. Menurut Kamus Besar Bahasa Indonesia, toleransi adalah penyimpangan yang masih dapat diterima dalam pengukuran kerja atau batas ukur untuk penambahan atau pengurangan yang masih diperbolehkan. Jadi, inti dari istilah tersebut adalah keadaan mampu saling menghormati dan saling memahami berbagai hal yang menurut perspektif golongan tertentu adalah penyimpangan, tentunya dengan batas ukur yang disepakati oleh seluruh lapisan masyarakat.

Sebuah masyarakat dapat dikatakan masyarakat yang toleran bila mampu menyikapi berbagai perbedaan yang tersaji, baik agama maupun etnis, dengan damai. Masyarakat yang toleran bukanlah masyarakat yang tidak pernah tersentuh konflik atau gesekan antar individunya. Hal ini dikarenakan keadaan toleran dan intoleran tidak bersifat statis dan tetap. Keadaan ini perlu diletakkan pada sebuah spektrum. Dalam satu waktu, suatu wilayah dapat menjadi sangat toleran dibandingkan wilayah-wilayah sekitarnya. Namun di lain waktu, dengan adanya berbagai perubahan kondisi sosial politik atau perubahan lainnya, wilayah tersebut menjadi sangat intoleran dibanding sekitarnya. Oleh karena itu, masyarakat yang toleran adalah masyarakat yang mampu menekan angka lahirnya konflik dan bila terlanjur terjadi konflik, berusaha meredamnya dengan jalan damai, sehingga tidak sampai melahirkan kekerasan komunal.

Perlu dipahami bahwa lahirnya suatu konflik menurut Pruitt dan Rubin merupakan dampak adanya interest yang bertentangan dari dua kelompok atau beberapa interest yang tidak dapat dipertemukan satu sama lain. ${ }^{1}$ Toleransi adalah sikap menghormati dan mengkondisikan interest-interest yang berbeda ini. Adapun intoleransi bukanlah sebuah "hasil" tapi juga sebuah gejala-gejala yang bisa dideteksi dalam bentuk tindakan tertentu. Bentuk-bentuk gejala intoleransi antara lain dengan bahasa, streotip, mengolok-olok, buruk sangka,

1 Dean G. Pruitt \& Jeffrey Z. Rubin, Teori Konfik Sosial, Terj. Helly P Soetijpto dan Sri Mulyantini Soetjipto. (Yogyakarta: Pustaka Pelajar, 2014), 10. 
pengkambinghitaman, diskriminasi, pengabaian, pelecehan, gertakan, pengusiran, pengecualian, segregasi, penindasan dan penumpasan. ${ }^{2}$ Dalam hal hubungan keagamaan, bentuk-bentuk pelanggaran yang mengindikasikan intoleransi adalah pemaksaan dengan intimidasi atau ancaman fisik, pemaksaan ancaman hukum, kriminalisasi keyakinan, pembatasan ibadah, pelarangan ibadah, pembiaran, pembatasan dan pelarangan aktivitas keagamaan dan penyegelan rumah ibadah. ${ }^{3}$

\section{METODE}

Dalam mengungkapkan penyebab terwujudnya toleransi atau intoleransi, penulis menggunakan pendekatan teori tentang tiga dimensi konflik dari Jayne Docherty ${ }^{4}$ dan Lisa Schirch ${ }^{5}$. Menurut keduanya, ketiga dimensi konflik tersebut adalah dimensi simbolik, dimensi relasional dan dimensi struktural. Ketiga dimensi tersebut memiliki hubungan yang erat dengan terciptanya konflik atau kerukunan di suatu wilayah. Dimensi simbolik berkaitan dengan nilai universal yang memungkinkan kelompok yang berbeda menemukan titik temu. Dimensi ini juga merupakan shared identity, baik yang telah ada dalam nilai masing-masing masyarakat (given) maupun nilai yang dibentuk oleh masyarakat yang ada (constructed).

Dimensi relasional berkaitan dengan hubungan sosial antar satu sama lain yang memungkinkan terjadinya interaksi antar agama dan antar etnis yang berbeda. Dalam istilah Ashutosh Varshney ${ }^{6}$, dimensi ini disebut civic engagement (pertunangan kemasyarakatan). Bentuk civic engagement ini dapat berupa formal seperti organisasi sosial, asosiasi perdagangan, koperasi dan klub olahraga dan minat bakat yang beranggotakan dari berbagai etnis dan kalangan, maupun informal seperti interaksi saling mengunjungi saat ada perayaan, perjumpaan di lingkungan sekitar, seperti pasar dan angkutan umum dan ruang-ruang publik

2 Laporan Tahunan Kebebasan Beragama/Berkeyakinan dan Intoleransi 2014: "Utang" Warisan Pemerintah Baru, (Jakarta: The Wahid Institute, 2014), 16-17

${ }^{3}$ Ibid, 14.

${ }^{4}$ Dalam Ahnaf, M. Iqbal, et.al, Toleransi dan Intoleransi di Indonesia: Kajian Atas Kultur Toleransi di Tengah Arus Perubahan Sosial di Kota Kupang, Nusa Tenggara Timur dalam Studi Tentang Toleransi dan Radikalisme di Indonesia, (Jakarta: INFID, 2016), 158-196

${ }^{5}$ Dalam Susanna Campbell, What Is Successful Peacebuilding? A Report prepared for Catholic Relief Services 2007, (Maryland: CRS, 2007), 5

${ }^{6}$ Ashutosh Varshney, Postmodernism, Civic Engagement and Ethnic Conflict: A Passage to India dalam jurnal Comparative Politics, Vol. 30, No.1 (New York: Political Science in City University of New York, Oct. 1997), 4 
lainnya. Dimensi ini menuntut manusia kembali ke fitrah mereka sebagai makhluk sosial yang tidak mampu hidup seorang diri atau hanya berkutat pada kelompok mereka yang homogen, melainkan memerlukan bantuan pihak lain yang berbeda identitasnya. Terakhir adalah dimensi struktural yang berkaitan dengan institusi dan wadah sosial, baik ekonomi, politik maupun pendidikan. Dalam dimensi ini, prinsip keadilan dan kesetaraan menjadi kunci dari interaksi yang terjalin. Timbulnya perasaan terdholimi atau tidak adanya simbiosis mutualisme bagi seluruh anggota sering menjadi pemicu lahirnya konflik.

Kajian akan praktek dialog antar agama tidak selalu berbicara tentang lahirnya konflik, lahirnya konflik dan penyelesaian konflik. Para aktivis dialog juga harus mengkaji kerukunan antar umat beragama yang telah terbangun, sebab-sebab kerukunan, sejauh mana masyarakat yang plural dapat mempertahankan koeksistensi tersebut dan memperkuat pondasi kerukunan yang telah tertanam. Sebagaimana sebab konflik yang berbeda antara satu wilayah dengan wilayah lain, sebab rukun pun beragam dan bervariasi. Ketiga dimensi konflik yang disebutkan di atas dalam satu wilayah dapat terpenuhi semua dan saling berhubungan satu sama lain. Namun tidak menutup kemungkinan hanya beberapa dimensi (atau hanya satu) yang menonjol dan sudah cukup untuk menjadi sebab rukun atau konflik suatu wilayah.

\section{KERAGAMAN DI MAMAHAK TEBOQ}

Desa Mamahak Teboq terletak di Kecamatan Long Hubung Kabupaten Mahakam Ulu (Mahulu) Provinsi Kalimantan Timur. Kabupaten Mahulu merupakan kabupaten baru di Provinsi Kalimantan Timur yang merupakan hasil pemekaran dari Kabupaten Kutai Barat. Kabupaten ini disahkan pada 20 Mei 2013 dengan luas wilayah $15.315 \mathrm{~km}^{2}$ dan total penduduk 27.923 jiwa (pada 2012). Kabupaten ini memiliki 5 kecamatan yaitu Long Apari, Long Pahangai, Long Bagun, Long Hubung dan Laham. Total penduduk di kecamatan Long Hubung sebanyak 8.194 orang dengan 1.990 kepala rumah tangga terdiri dari 4.410 laki-laki dan 3.784 perempuan, dengan kepadatan rata-rata: 15,43 jiwa $/ \mathrm{km}^{2}$. Secara lebih detail, berikut adalah tabel penduduk kecamatan Long Hubung per desa ${ }^{7}$

7 Diolah dari berbagai Sumber : Dinas Kependudukan, Catatan Sipil dan Keluarga Berencana Kabupaten Kutai Barat 2008; Rekapitulasi Penduduk Kecamatan Long Hubung 2010 dalam Draft Laporan Akhir tahun 2010: Identifikasi Kawasan Bernilai Konservasi Tinggi PT. Ratah Timber Kalimantan Timur, (Bogor: Ideas Consultancy Services, 2010), 54-55. 


\begin{tabular}{|l|c|c|c|c|c|l|}
\hline \multicolumn{1}{|c|}{ Desa } & $\begin{array}{c}\text { Jumlah } \\
\text { Jiwa }\end{array}$ & $\begin{array}{c}\text { Jumlah } \\
\text { KK }\end{array}$ & $\begin{array}{c}\text { Pendud } \\
\text { uk per } \\
\text { KK } \\
\text { (jiwa) }\end{array}$ & $\begin{array}{c}\text { Jumlah } \\
\text { Laki- } \\
\text { laki }\end{array}$ & $\begin{array}{c}\text { Jumlah } \\
\text { Perem- } \\
\text { puan }\end{array}$ & $\begin{array}{c}\text { Kecama } \\
\text { tan }\end{array}$ \\
\hline $\begin{array}{l}\text { Mamahak } \\
\text { Teboq dan } \\
\text { Sirau }\end{array}$ & 1.480 & 385 & 3,84 & 782 & 698 & $\begin{array}{l}\text { Long } \\
\text { Hubung }\end{array}$ \\
\hline Lutan & 751 & 186 & 4,04 & 430 & 321 & $\begin{array}{l}\text { Long } \\
\text { Hubung }\end{array}$ \\
\hline $\begin{array}{l}\text { Datah Bilang } \\
\text { Ulu }\end{array}$ & 2.137 & 485 & 4,41 & 1156 & 981 & $\begin{array}{l}\text { Long } \\
\text { Hubung }\end{array}$ \\
\hline Long Hubung & 1.353 & 303 & 4,47 & 754 & 608 & $\begin{array}{l}\text { Long } \\
\text { Hubung }\end{array}$ \\
\hline
\end{tabular}

Adapun berdasarkan etnisitas, kecamatan ini didominasi oleh suku Dayak dari berbagai sub-suku yang beragam, baik Dayak Bahau Umaq Luhat, Dayak Kenyah, Dayak Punan maupun sub-suku Dayak lainnya. Selain suku Dayak sebagai penduduk asli, terdapat pula suku pendatang yang berasal dari Suku Banjar (Kalsel), suku Jawa, Sunda, Bugis, dan etnis China. Sebagian besar dari mereka berperan sebagai Pedagang, Pegawai Negeri, Guru, TNI, maupun buruh perusahaan. Adapun penduduk asli lebih banyak bermata pencaharian di bidang pertanian dengan pola perladangan (gilir balik) yang menjadi warisan turun temurun keluarga mereka. Tidak heran prosentase keluarga pertanian menyentuh angka 90\% di mayoritas desa di kecamatan ini.

Kecamatan ini memiliki penduduk dengan keberagaman agama dan kepercayaan namun memiliki sikap toleransi dan kerukunan tinggi. Berikut adalah tabel jumlah pemeluk agama Mamahak Teboq dengan desa lain di sekitarnya di kecamatan Long Hubung dan Laham 8 :

Tabel 1. Tabel Jumlah Pemeluk Agama

\begin{tabular}{|l|c|c|c|c|c|c|}
\hline \multirow{2}{*}{ Desa } & Jumlah & \multicolumn{5}{c|}{ Jumlah Pemeluk Agama } \\
\cline { 3 - 7 } & Penduduk & Katolik & Kristen & Islam & Hindu & Budha \\
\hline Laham & 1139 & 1022 & 28 & 89 & - & - \\
\hline
\end{tabular}

${ }^{8}$ Rekapitulasi Penduduk Kecamatan Laham 2010, Hasil Studi PRA WWF Indonesia 2010 dalam Draft Laporan Akhir tahun 2010: Identifikasi Kawasan Bernilai Konservasi Tinggi PT. Ratah Timber Kalimantan Timur, (Bogor: Ideas Consultancy Services, 2010), 58 


\begin{tabular}{|l|c|c|c|c|c|c|}
\hline Muara Ratah & 204 & - & - & 204 & - & - \\
\hline Danum Paroy & 555 & 44 & 120 & 328 & 63 & - \\
\hline Long Gelawang & 492 & 217 & - & 275 & - & - \\
\hline Nyerbungan & 158 & 8 & 94 & 56 & - & - \\
\hline Desa Lutan & 218 & - & 413 & 414 & - & - \\
\hline Mamahak Teboq & 1444 & - & 1299 & 144 & - & - \\
\hline
\end{tabular}

Dari tabel tersebut dapat ditemukan bahwa Mamahak Teboq memiliki jumlah penduduk terbanyak dan perbandingan umat beragama yang tinggi dibanding desa lainnya. Desa ini juga hanya memiliki dua agama besar yang dianut, yaitu Kristen Protestan dan Islam. Data inilah yang membuat penulis memilih desa tersebut sebagai model toleransi antar umat beragama dengan Kristen sebagai mayoritas dan Islam sebagai minoritas, sebuah fenomena unik di negeri berpenduduk muslim terbesar di dunia.

Penduduk muslim di sana sebagian besar adalah pendatang dari berbagai suku (Jawa, Banjar, Sunda, dll) dan bekerja di perusahaan pengolahan kayu yang berbatasan langsung dengan desa tersebut. Suku pendatang ini bersifat tidak tetap karena tinggal di sana sesuai kontrak kerja yang ada. Adapun di desa terdapat satu kelompok masyarakat suku Bugis yang menjadi penduduk tetap desa tersebut. Hubungan antara penduduk asli dan pendatang, baik suku Bugis yang menetap maupun pegawai perusahaan yang tidak tetap menjadi fokus tulisan ini untuk menunjukkan tingkat toleransi atau intoleransi di desa tersebut.

\section{GEJALA TOLERANSI DAN INTOLERANSI}

Banyaknya suku Dayak yang beragama Protestan di Mamahak Teboq tidak serta merta mendominasi para minoritas pendatang. Pengalaman pribadi penulis saat berada di tengah-tengah kampung tersebut pada pendatang disambut dengan baik dan ramah. Mereka bahkan menganggap saudara mereka, apapun etnis dan sukunya, apapun agama dan kepercayaannya. Istilah penduduk asli dan pendatang pun seakan tidak ada dan tidak pernah menjadi permasalahan serius. Para pendatang pun merasa kampung tersebut bagaikan kampung halaman sendiri. Meski terdapat beberapa kendala dalam bahasa, karena beberapa tetua kampung tidak dapat berbahasa Indonesia, namun seiring berjalannya waktu hal tersebut tidak menjadi hambatan yang berarti dalam hidup berdampingan.

Wawancara yang dilakukan penulis dengan Manager Camp Perusahaan, karyawan perusahaan dan warga sekitar juga dapat disimpulkan jarang terjadi 
gesekan terutama karena alasan agama dan etnisitas. Sedikitnya ada beberapa fenomena yang dapat dijadikan indikasi toleransi di Mamahak Teboq.

Pertama, seluruh warga, baik yang menetap maupun karyawan perusahaan yang tinggal di camp, dilibatkan dalam berbagai upacara-upacara adat. Salah satu upacara yang rutin dilakukan adalah Tarian Hudoq yang diselenggarakan tiap sebelum dan sesudah panen. Dalam perayaan ini, semua elemen masyarakat dilibatkan, baik sebagai panitia persiapan maupun sebagai peserta. Namun perayaan adat ini masih menghormati kepercayaan kaum Muslim yang tidak memakan babi, meminum buraq (sejenis tuak yang berasal dari fermentasi tape singkong), bermain judi dan sabung ayam. Penduduk setempat yang masih menjalankan berbagai ritual tersebut juga tidak pernah memaksa mereka yang muslim untuk bergabung dengan kegiatan mereka yang dipandang haram dalam agama Islam.

Kedua, pesta pernikahan. Menurut tradisi setempat, pernikahan antar suku Dayak dan non-Dayak tidak pernah dipermasalahkan. Adapun untuk pernikahan di desa ini, pesta digelar selama 7 hari 7 malam dengan berbagai hiburan dan sajian. Di sekeliling tempat pesta juga berdiri sejenis pasar malam yang menjual berbagai macam makanan. Dalam momen ini, pihak tuan rumah juga mengundang seluruh kalangan untuk dapat hadir dalam pesta. Makanan yang disediakan pun beragam dan terpisah. Bagi tamu yang beragama muslim, mereka menyediakan tempat khusus dan tertutup untuk sajian makan. Makanan yang dihidangkan pun makanan yang halal dikonsumsi oleh muslim, yang dimasak oleh orang muslim dan menggunakan peralatan masak dan makan yang khusus. Mereka menghormati kepercayaan muslim yang tidak mengkonsumsi daging babi. Karena bagi mereka, acara-acara besar seperti ini tidaklah sempurna tanpa adanya daging babi guling, daging babi panggang dan makanan olahan babi lainnya, juga tak lupa dengan buraq berliter-liter.

Ketiga, pembangunan rumah ibadah yang terlepas dari konflik dan sengketa. Penduduk asli di sana tidak mempermasalahkan berdirinya masjid di tengah-tengah kampung mereka, lengkap dengan pengeras suaranya. Meski jumlah muslim yang menunaikan shalat Jum'at hanya sedikit (saat itu penulis menghitung tidak lebih dari 40 pria), penghuni sekitar masjid tidak keberatan dengan suara adzan dan khutbah dengan pengeras suara yang bergema di seluruh desa. Saat ramadhan tiba, para pekerja non-muslim juga ikut menyesuaikan diri dengan jam kerja muslim yang berpuasa. Mereka ada yang membantu memasakkan makanan sahur, makanan untuk berbuka dan tidak makan dan minum langsung di depan pegawai yang muslim. Masyarakat muslim, khususnya 
pegawai camp juga siap bergotong royong memperbaiki gereja yang rusak. Sebelum tahun 2010, pegawai camp merenovasi gereja yang berada di sekitar pemukiman pegawai. Gereja tersebut rusak parah dan sudah lama tidak terpakai, namun atas masukan beberapa pegawai dan penduduk sekitar, pihak perusahaan berinisiatif merenovasi gereja tersebut dengan bantuan berbagai pihak.

Keadaan toleransi yang demikian tidak berarti bebas 100\% dari berbagai gesekan dan tindakan intoleransi meski hanya sedikit sekali. Dari beberapa wawancara, sedikitnya ada 3 hal yang menjadi riak-riak dalam lautan keberagaman di Mamahak Teboq. Pertama, tradisi warga setempat untuk memelihara anjing dan babi terkadang menganggu aktivitas warga lainnya, khususnya yang muslim. Anjing dan babi tersebut dibiarkan berkeliaran di berbagai tempat, tidur di teras rumah penduduk muslim, buang air di berbagai tempat bahkan pernah menggigit warga sekitar. Anjing sendiri mendapat tempat yang terhormat di mata penduduk setempat. Bila seekor anjing mati tertabrak kendaraan, sengaja atau tidak sengaja, maka ganti rugi yang dikenakan sangat besar. Biaya ganti rugi akan semakin besar bila yang mati adalah anjing betina atau sedang hamil. Ganti rugi dikalikan jumlah puting susu anjing tersebut.

Kedua, adanya kelompok masyarakat Bugis yang tinggal dan menetap di tengah kampung yang menolak membaur dengan warga Dayak. Mereka acapkali menolak menghadiri undangan pernikahan atau perayaan adat yang diadakan warga setempat. Masyarakat Bugis yang beragama Islam ini juga sangat jarang terlihat berinteraksi dengan warga setempat yang beragama Kristen. Mereka lebih memilih berinteraksi dengan mereka yang satu suku dan suku agama. Sikap ini sudah dipahami oleh warga setempat dan sering membuat mereka malas untuk bergaul dengan masyarakat Bugis. Namun dalam berbagai upacara dan perayaan, mereka tetap menyertakan undangan bagi mereka meski kemungkinan untuk dapat dihadiri kecil.

Ketiga, adanya provokasi dari luar. Berbagai LSM yang mengatasnamakan keluarga Dayak dari luar Mamahak Teboq merasa desa tersebut sudah terekspolitasi oleh kegiatan perusahaan. Mereka banyak menuntut ganti rugi dan kompensasi kepada perusahaan dengan berbagai dalih dan alasan, yang mana hal tersebut tidak pernah diminta oleh penduduk setempat. Seperti sengketa kayu ulin, proposal pembelian alat berat dan berbagai masalah ekonomi lainnya. Hal ini juga berpotensi menggoyahkan pondasi kerukunan yang telah terbangun. Namun warga desa tidak terprovokasi dan tetap menjalin hubungan baik dengan perusahaan dan seluruh pegawainya. 


\section{SEBAB TOLERANSI DI MAMAHAK TEBOQ}

Contoh-contoh di atas menunjukkan bagaiman kuatnya kultur damai dan toleransi di Mamahak Teboq. Meski riak-riak intoleransi muncul karena interest satu dua kelompok, namun tidak dapat meruntuhkan nilai-nilai toleransi yang ada. Pada bahasan ini, penulis mencoba memaparkan sebab-sebab kuatnya toleransi dan kokohnya kerukunan di Mamahak Teboq dengan menggunakan teori tiga dimensi konflik, yaitu simbolik, relasional dan struktural.

Pada dimensi simbolik, ditemukan adanya memori damai yang telah tertanam sejak dahulu kala. Penduduk asli dari suku Dayak tidak pernah memiliki momen buruk dengan para pendatang dan sudah menjadi tradisi mereka untuk selalu membantu dan menghormati tamu. Berdasarkan kepercayaan dan tradisi mereka, manusia adalah sahabat alam dan seisinya. Bila dengan alam yang berbeda spesies saja mereka harus berbuat baik, mengapa dengan pendatang yang masih satu spesies tidak dapat berdamai? Inilah penyebab mengapa kekerasan komunal di Sampit, meski melibatkan suku Dayak tidak merambat ke suku-suku Dayak lain.

Pada dimensi relasional, sebab lahirnya toleransi di desa lebih terasa. Dalam kehidupan sehari-hari, tingkat interaksi penduduk asli dan penduduk sekitar cukup tinggi. Selain upacara adat dan perayaan pernikahan, mereka juga sering bertemu di pasar, di taksi (sebutan untuk perahu yang digunakan menyusuri sungai Mahakam), saat memancing, saat mencari buah-buahan di hutan dan saat di ladang. Keberadaan koperasi perusahaan juga cukup memudahkan warga sekitar untuk berbelanja kebutuhan sehari-hari dibandingkan menunggu kapal sembako yang berlabuh sebulan sekali atau ke pasar yang terletak cukup jauh. Di koperasi inilah, interaksi kecil antara penduduk asli dan pegawai perusahaan sering terjalin. Selain itu, ibu-ibu dan anak-anak sekitar sering duduk bersama di siang dan sore hari untuk bercengkrama dan menco' (makan rujak buah bersama).

Saat perayaan hari-hari besar, seperti Idul Fitri dan Natal, terdapat tradisi saling mengunjungi mereka yang merayakannya. Saat Idul Fitri tiba, penduduk sekitar berbondong-bondong mengunjungi saudara mereka yang muslim. Sebaliknya, saat perayaan Natal tiba, kelompok muslim juga mengunjungi rumah mereka yang merayakan. Bila tidak dapat ke seluruh rumah, mereka cukup menghadiri perayaan besar yang diadakan di tanah lapang di desa. Diluar harihari besar tersebut, mereka juga sering mengunjungi kerabat yang sedang sakit atau ditimpa musibah seperti kebakaran atau meninggalnya sanak keluarga 
mereka. Mereka juga membantu memanggil pak Mantri (juru rawat perusahaan) untuk memberi pertolongan pertama. Pengurusan jenazah juga dilakukan bersama-sama tanpa memperdulikan perbedaan etnis dan agama yang ada.

Jalinan relasional ini semakin diperkuat dengan adanya forum-forum formal yang memungkinkan adanya interaksi antar penduduk asli dan pendatang. Dalam bidang pendidikan, kesehatan, keagamaan, dan sosial budaya, perusahaan sering mengadakan kegiatan-kegiatan yang melibatkan langsung penduduk sekitar, baik sebagai obyek maupun subyek. Selain memberikan bantuan materiil berupa sarana ibadah, sarana pendidikan, dan dana pendidikan, pihak perusahaan juga mengadakan pengobatan gratis, posyandu, fogging di sekitar desa, dan mengajar di sekolah-sekolah yang ada. Semua kegiatan yang masuk dalam rangkaian program "Pemberdayaan Masyarakat Desa Hutan (PMDH)" ini semakin menciptakan hubungan dan interaksi yang semakin intens dan hangat. Berbagai isu-isu intoleransi dapat langsung dikonfirmasi dan diklarifikasi dalam berbagai forum tersebut. Sayangnya, hal ini belum dapat menggugah kesadaran suku Bugis Muslim di tengah desa untuk ikut berbaur dengan masyarakat lainnya.

Pada dimensi struktural, yang berkaitan dengan pola hubungan ekonomi dan kekuasaan, wajah toleransi juga cukup tampak di desa ini. Dari segi ekonomi, sebagaimana sedikit disinggung di atas, keberadaan koperasi perusahaan berperan dalam mencukupi kebutuhan sehari-hari warga desa sekitar. Disamping itu, hasil ikan, hasil ladang, dan hasil hutan yang dibutuhkan para pegawai camp perusahaan disediakan oleh penduduk asli yang mayoritas berkecimpung di bidang pertanian, sebagaimana ditunjukkan oleh tabel berikut:

Tabel 2. Presentasi Keluarga Pertanian di Kecamatan Laham dan Long Hubung

\begin{tabular}{|l|l|c|l|}
\hline \multicolumn{1}{|c|}{ Desa $^{9}$} & \multicolumn{1}{|c|}{$\begin{array}{c}\text { Etnis/suku } \\
\text { Terbesar }\end{array}$} & $\begin{array}{c}\text { Keluarga } \\
\text { Pertanian (\%) }\end{array}$ & \multicolumn{1}{|c|}{ Kecamatan } \\
\hline Long Gelawang & Dayak Bahau & 90 & Laham \\
\hline
\end{tabular}

9 Sumber: Rekapitulasi Penduduk Kecamatan Long Hubung 2008 dan Rekapitulasi Penduduk Kecamatan Laham 2008 dalam Draft Laporan Akhir tahun 2010: Identifikasi Kawasan Bernilai Konservasi Tinggi PT. Ratah Timber Kalimantan Timur, (Bogor: Ideas Consultancy Services, 2010), 57. 
176 /Yuangga Kurnia Y.

\begin{tabular}{|l|l|c|l|}
\hline Muara Ratah & Dayak Punan & 90 & Laham \\
\hline Danum Paroy & Dayak punan & 70 & Laham \\
\hline Laham & Dayak Punan & 90 & Laham \\
\hline Nyerbungan & Dayak punan & -- & Laham \\
\hline Mamahak Teboq & Dayak Bahau & 92 & Long Hubung \\
\hline Lutan & Dayak Bahau & 94 & Long Hubung \\
\hline Datah Bilang Ilir & Dayak Kenyah & 75 & Long Hubung \\
\hline Datah Bilang Ulu & Dayak Kenyah & 91 & Long Hubung \\
\hline Long Hubung & Dayak Bahau & 75 & Long Hubung \\
\hline Mata Libaq & Dayak Bahau & 99 & Long Hubung \\
\hline Wana Pariq & Dayak Bahau & 99 & Long Hubung \\
\hline Tri Pariq Makmur & Dayak Iban & 97 & Long Hubung \\
\hline
\end{tabular}

Tabel 3. Mata Pencaharian Penduduk

\begin{tabular}{|l|c|c|c|c|c|c|c|c|}
\hline \multirow{2}{*}{$\begin{array}{c}\text { Mata } \\
\text { Pencaharian10 }\end{array}$} & \multicolumn{2}{|c|}{ Desa Lutan } & \multicolumn{2}{c|}{ Danum Paroy } & \multicolumn{2}{c|}{$\begin{array}{c}\text { Long } \\
\text { Gelawang }\end{array}$} & \multicolumn{2}{c|}{$\begin{array}{c}\text { Mamahak } \\
\text { Teboq }\end{array}$} \\
\cline { 2 - 9 } & Orang & $\mathbf{\%}$ & Orang & $\mathbf{\%}$ & Orang & \% & Orang & \% \\
\hline Bertani & 204 & 94 & 110 & 80 & 108 & 88 & 305 & 80 \\
\hline Berdagang & 7 & 3 & 5 & 4 & 2 & 2 & 19 & 5 \\
\hline Swasta & 4 & 2 & 20 & 15 & - & - & 38 & 10 \\
\hline Cari hasil hutan & - & - & - & - & 10 & 8 & 11 & 3 \\
\hline PNS & 3 & 1 & 2 & 1 & 3 & 2 & 8 & 2 \\
\hline beternak & - & - & - & - & - & - & & - \\
\hline Jumlah & 218 & 100 & 137 & 100 & 123 & 100 & 381 & 100 \\
\hline
\end{tabular}

Di samping itu, kehadiran perusahaan ini juga banyak membantu perekonomian dan kesejahteraan penduduk asli. Berdasarkan skripsi Ribkha Sinaga dari Departemen Manajemen Kehutanan Fakultas Kehutanan Institut Pertanian Bogor yang disusun tahun 2011, perusahaan ini berkontribusi terhadap tenaga kerja dimana 93,59\% pegawai di base camp merupakan penduduk sekitar (Sinaga, 2011: 68). Indikasi lainnya adalah pendapat berbagai responden yang terdiri dari penduduk sekitar akan bentuk kontribusi perusahaan terhadap penduduk sekitar. Sekitar $76,67 \%$ responden mengatakan bahwa perusahaan

10 Data primer dari Studi PRA WWF Indonesia, 2010 dalam dalam Draft Laporan Akhir tahun 2010: Identifikasi Kawasan Bernilai Konservasi Tinggi PT. Ratah Timber Kalimantan Timur, (Bogor: Ideas Consultancy Services, 2010), 57 
tersebut berkontribusi terhadap aksesibilitas, 83,33\% responden mengatakan bahwa perusahaan berkontribusi pada kesempatan berusaha, 63,63\% responden mengatakan bahwa perusahaan berkontribusi terhadap peningkatan kapasitas SDM dan 84,62\% responden mengatakan perusahaan berkontribusi terhadap pembangunan sarana dan prasarana. ${ }^{11}$

Dari segi lingkungan, hubungan baik antara perusahaan dan penduduk asli juga berkontribusi besar dalam pelestarian lingkungan hutan. Sistem pertanian ladang (gilir balik) atau lading berpindah yang menjadi tradisi penduduk asli juga berpotensi besar mengurangi kelestarian hutan. Penyuluhan dan pengorganisiran sistem perladangan penduduk asli oleh perusahaan mampu meminimalisir potensi kerusakan ekosistem dan ekologi hutan di daerah tersebut. Berbagai tumbuhan langka dan hewan langka yang ditemukan di sekitar wilayah produksi juga dapat dilestarikan dan dijaga dari kepunahan.

Untuk bidang kekuasaan, tidak terdapat perbedaan mencolok antara penduduk asli dan pendatang. Di wilayah pemerintahan masih di dominasi oleh penduduk lokal atau yang bersuku Dayak. Adapun dalam lingkup desa ini, kepala manager camp, eksekutif perusahaan dan pengurus sentral berasal dari pendatang dan beragama Islam. Untuk penduduk sekitar menempati berbagai posisi yang tersebar di perusahaan tersebut. Hal ini pula yang sesekali memantik kecemburuan sosial terhadap jabatan di perusahaan, mengingat para pendatang memiliki jenjang pendidikan minimal D3 dan Sarjana Strata 1, sebaliknya penduduk asli banyak yang merupakan lulusan Sekolah Dasar (SD) dan Sekolah Menengah (SMP dan SMA). Namun kecemburuan ini hanya timbul di beberapa individu saja, mengingat pesatnya perekonomian mereka sejak perusahaan tersebut berdiri pada 1970.

Menurut pengamatan penulis, basis toleransi di Mamahak Teboq terasa sangat kuat pada dimensi relasional dan struktural. Perasaan perbaikan taraf kehidupan setelah adanya pendatang menimbulkan rasa respect dan terbuka dari penduduk asli. Pihak perusahaan juga merasa terbantu dengan sikap terbuka penduduk asli demi kemajuan perusahaan dan daerah secara khusus, dan demi kelestarian lingkungan hutan di Kalimantan umumnya. Hal ini merujuk pada data yang dikeluarkan oleh Kementrian Kehutanan yang menyebutkan sedikitnya 1,1

11 Ribkha Sinaga, Kontribusi IUPHHK-HA PT. Ratah Timber Terhadap Pembangunan Daerah Kecamatan Long Hubung, Kab. Kutai Barat, Kalimantan Timur. Skripsi Departemen Manajemen Kehutanan, Fakultas Kehutanan, Institut Pertanian Bogor, (Bogor: IPB, 2011), 68 
juta hektar atau 2\% hutan di Indonesia menyusut tiap tahunnya. Dari semula sebanyak 130 juta hektar hutan yang tersisa di Indonesia, sekitar 42 juta hektar diantaranya telah rusak karena penebangan liar dan kebakaran (wwf.or.id). Karenanya, perbedaan ras, etnis dan agama tidak pernah menjadi masalah serius di sana. Toleransi yang baik antara kedua pihak ini juga turut serta membangun "toleransi" terhadap lingkungan.

\section{PENUTUP}

Toleransi atas keragaman di Mamahak Teboq seolah membuktikan statement bahwa toleransi yang ditampakkan non-muslim di Indonesia hanyalah kedok belaka. Hal ini mereka lakukan karena mereka menjadi minoritas dari segi jumlah di negeri ini. Sejatinya, sikap toleransi yang sesungguhnya dapat dilihat saat dalam posisi kuat atau mayoritas. Adapun toleransi saat di posisi minoritas merupakan sikap yang amat mudah dilakukan demi menjamin eksistensi mereka dan mendapatkan rasa aman dari dominasi mayoritas.

Berbicara tentang mayoritas-minoritas tidak melulu terpaku pada jumlah (kuantitas), namun juga pada pengaruh maupun ideologi. Isu mayoritasminoritas seringkali menjadi alibi dan "posisi", untuk melegalkan berbagai konflik demi tercapainya interest golongan tertentu. Karenanya dibutuhkan sikap saling percaya dan membuat banyak ruang perjumpaan guna mengantisipasi terjadinya disinformasi antar masyarakat yang plural. Hal ini yang menjadi salah satu tugas aktivis dialog dan perdamaian.

Ruang perjumpaan di Mamahak Teboq juga tidak selalu bersifat formal, pengaruh terbesar justru muncul dari forum semi-formal dan informal antar masyarakat. Minimnya kesenjangan sosial yang muncul dari kedua belah pihak disinyalir menjadi perekat hubungan mereka. Menjadi penting adanya institusionalisasi nilai-nilai dengan aksi dan ritus, seperti perayaan adat bersama dan perayaan hari-hari besar keagamaan bersama dan tidak berhenti di ucapan dan keyakinan saja. Momen-momen inilah yang menjadi pengingat akan kerukunan yang telah tercipta dan berfungsi sebagai pupuk penyubur benihbenih toleransi yang telah tertanam sejak dahulu.

Namun keadaan demikian tidak dapat bertahan selamanya. Selalu ada pihak-pihak dari luar yang merongrong atmosfer toleransi di Mamahak Teboq. Dengan isu ekonomi, sosial dan budaya mereka mencoba memprovokasi penduduk sekitar untuk memutus berbagai kerja sama yang telah terbangun. Para pemuda suku Dayak yang bersekolah di kota juga tidak sedikit yang terpengaruh 
pola pikir yang salah akan hubungan ini. Mereka menganggap perusahaan hanya mengeruk keuntungan pribadi tanpa memerdulikan keadaan masyarakat asli tanpa sadar justru perusahaan tersebut mencoba menyelamatkan hutan dari berbagai tradisi yang tidak ramah lingkungan.

Akhirnya, keberlangsungan toleransi ini perlu dukungan dari berbagai pihak untuk menjadi lebih baik lagi. Para tokoh masyarakat dan pihak-pihak terkait diharapkan mampu meluluhkan hati kelompok tertentu yang masih sulit untuk berbaur dengan masyarakat asli. Koeksistensi daerah ini juga diharapkan dapat menjadi pemicu masyarakat plural di daerah lain untuk mulai menggiatkan toleransi atas keberagaman yang ada, khususnya di tengah derasnya arus perubahan sosial budaya yang tercipta.

\section{DAFTAR PUSTAKA}

Ahnaf, M. Iqbal, dkk. 2016. Toleransi dan Intoleransi di Indonesia: Kajian Atas Kultur Toleransi di Tengah Arus Perubahan Sosial di Kota Kupang, Nusa Tenggara Timur dalam Studi Tentang Toleransi dan Radikalisme di Indonesia. Jakarta: INFID, 206, 158-196

Campbell, Susanna. What Is Successful Peacebuilding? A Report prepared for Catholic Relief Services 2007. Maryland: CRS, 2007

Draft Laporan Akhir tahun 2010: Identifikasi Kawasan Bernilai Konservasi Tinggi PT. Ratah Timber Kalimantan Timur. Bogor: Ideas Consultancy Services, 2010.

Laporan Tahunan Kebebasan Beragama/Berkeyakinan dan Intoleransi 2014: "Utang" Warisan Pemerintah Baru. 2014. Jakarta: The Wahid Institute, 2014

Pruitt, Dean G. \& Jeffrey Z. Rubin. Teori Konfik Sosial, Terj. Helly P Soetijpto dan Sri Mulyantini Soetjipto. Yogyakarta: Pustaka Pelajar, 2004

Sinaga, Ribkha. Kontribusi IUPHHK-HA PT. Ratah Timber Terhadap Pembangunan Daerah Kecamatan Long Hubung, Kab. Kutai Barat, Kalimantan Timur. Skripsi Departemen Manajemen Kehutanan, Fakultas Kehutanan, Institut Pertanian Bogor, 2011

Varshney, Ashutosh. Postmodernism, Civic Engagement and Ethnic Conflict: A Passage to India dalam jurnal Comparative Politics, Vol. 30, No.1, Oct. 1997. New York: Political Science in City University of New York, 1997, 1 - 20. 
180 /Yuangga Kurnia Y.

http://www.wwf.or.id/tentang_wwf/upaya_kami/forest_spesies/tentang_forest _spesies/kehutanan 